\title{
LWOWSCY FILOLODZY KLASYCZNI I NOWOŻYTNI W ROLI HISTORYKÓW LITERATURY POLSKIEJ
}

\author{
Mariusz Chrostek \\ Uniwersytet Rzeszowski
}

\section{ABSTRACT \\ LVIV CLASSICAL AND MODERN PHILOLOGISTS IN THE ROLE OF HISTORIANS OF POLISH LITERATURE}

The influence of antiquity, especially of the heritage of Greece and Rome on Polish literature, as well as of the Latin literature on the development of the national language, resulted in valuable monographs and studies by classical philologists. Zygmunt Węclewski became a pioneer in the study of Polish-Latin poetry. His achievements were continued by Ludwik Ćwikliński and Bronisław Kruczkiewicz. In the interwar period, Jerzy Kowalski became famous for his brilliant translations and editions of Adam Mickiewicz's Lausanne lectures. The greatest contributution from classical philologists to Polish literature came from Ryszard Ganszyniec. Also the Romanist Edward Porębowicz was an expert on Polish literature. His comparative studies included: the Baroque period, poetry of the Great Romantics, and poetry of the Young Poland. Another Romanist, Kazimierz Jarecki, contributed numerous articles devoted to Słowacki's works. Lviv Germanicists, Richard Maria Werner and Emil Petzold, showed many unknown connections between Mickiewicz's work and German literature. The only Lviv professor of the English studies, Władysław Tarnawski, published works on Cyprian Norwid and Jan Kasprowicz and popularized the works of Henryk Sienkiewicz. The overview of Polish literature specialists concludes with the figure of Jan Janów, a researcher of Polish Medieval and Renaissance literature and its reception on the Ukrainian soil.

Key words: Lviv, Jan Kazimierz University, classical philology, Romance studies, German studies, English studies, comparative studies.

Słowa kluczowe: Lwów, Uniwersytet Jana Kazimierza, filologia klasyczna, romanistyka, germanistyka, anglistyka, komparatystyczne badania.

Studia z zakresu literatury polskiej prowadzone przez grecystów, romanistów czy anglistów zwykło się nieraz traktować drugorzędnie wobec naukowych ustaleń polonistów, wychodząc - jakże niesłusznie! - z założenia, że rodzime piśmiennictwo nie 
stanowi głównego obszaru badawczej aktywności tych pierwszych. Fałszywe przeświadczenie, jakoby znawca Sofoklesa i wyborny tłumacz ód Horacego nie potrafił w równym stopniu orientować się w twórczości Jana Kochanowskiego, albo monografista Dantego nie osiągnął podobnej filologicznej precyzji, pochylając się nad liryką Jana Andrzeja Morsztyna, mógł się przyczynić do tego, że wiele znakomitych, nawet rewolucyjnych w swoim czasie opracowań dziś jest zupełnie zapomnianych. A przecież trzeba pamiętać, że zarówno w czasie zaborów, jak i w II Rzeczypospolitej wszechstronne humanistyczne wykształcenie, prowadzące w końcu do profesury i zapewniające kiedyś katedrę uniwersytecką, obejmowało co najmniej kilka dyscyplin czy - używając współczesnej terminologii - kierunków. Studiowało się zatem równolegle polonistykę, romanistykę, germanistykę, przeważnie też filozofię, nierzadko do tego historię. Najzdolniejsi doktorzy mogli wylegitymować się ukończeniem kilku europejskich uczelni. Taki germanista mógł pewną ręką kłaść na swoim filologicznym warsztacie Mickiewicza obok Goethego, podobnie jak polonista Szekspira obok Słowackiego.

Zainteresowania filologów klasycznych i nowożytnych twórczością polskich pisarzy wydawały owoce albo w postaci prac komparatystycznych (przemożny wpływ antyku, zwłaszcza dziedzictwa Grecji i Rzymu, na rodzimą literaturę, a łaciny dodatkowo na rozwój języka narodowego, później wzajemne oddziaływanie literatur i języków nowożytnych), albo monografii i studiów specjalnie poświęconych wybranym pisarzom czy zjawiskom w polskich realiach.

Spośród uczonych związanych z katedrami filologicznymi lwowskiego uniwersytetu $^{1}$ (przeważnie kierownikami tych jednostek) większość wniosła cenny wkład w badania literatury polskiej. Czasami ograniczał się on do paru przyczynków, częściej jednak tworzył pokaźny, liczący nawet kilkadziesiąt pozycji (obejmujący też książki) rozdział w bibliografii autora. Tematy badawcze realizowane przed wojną we Lwowie ci sami profesorowie kontynuowali niekiedy po roku 1945 na innym uniwersytecie. Zarówno ze względu na bogactwo i różnorodność polonistycznych pozycji w dorobku lwowskich filologów z innych katedr, jak i z uwagi na charakter niniejszej wypowiedzi (bliższej szkicowi niż rozprawie), prezentacja wielu zjawisk zostanie potraktowana sprawozdawczo, najważniejsze zaś ustalenia będą przypomniane $\mathrm{w}$ formie syntezy.

Pierwszeństwo według porządku chronologicznego należy się przedstawicielom filologii klasycznej. Od początku lat 70. XIX wieku działały na Uniwersytecie Lwowskim dwie katedry - pierwsza katedra (grecka), którą kierował od 1871 roku Zygmunt Węclewski, druga katedra (łacińska) prowadzona od 1876 roku przez Ludwika Ćwiklińskiego². Następcą Ćwiklińskiego został w 1902 roku Stanisław

1 Mowa tutaj o profesorach i docentach związanych z katedrami od początku ich istnienia do wybuchu II wojny światowej, czyli o pracownikach zarówno Uniwersytetu Lwowskiego, jak i Uniwersytetu Jana Kazimierza.

2 Zasługi obu nestorów lwowskiej filologii klasycznej utrwalił później inny wychowanek tej uczelni, także filolog klasyczny, Jan Smereka. Zob. J. Smereka, Filologia klasyczna w Uniwersytecie Lwowskim do czasów Zygmunta Węclewskiego i Ludwika Ćwiklińskiego, Lwów 1937 (odbitka z „Eos” 1937); idem, Pierwszy filolog-Polak w Uniwersytecie Jana Kazimierza Zygmunt Węclewski, Lwów 1938. 
Witkowski i pełnił tę funkcję do 1935 roku. Po śmierci Węclewskiego (1887) katedrę grecką przejął natomiast Bronisław Kruczkiewicz (do 1918 r.), a od 1920 do 1939 roku kierował nią Jerzy Kowalski. Trzecia, najmłodsza katedra, utworzona w 1920 roku ad personam, przypadła zaproszonemu z Poznania zaledwie 32-letniemu Ryszardowi Ganszyńcowi (Gansińcowi), który też najwięcej spośród tego grona zrobił dla przybliżenia tajników dawnej polskiej literatury. Stery katedry utrzymał Ganszyniec przez całe dwudziestolecie (do 1939 r.), ale też przez pierwsze lata wojennej zawieruchy (1939-1941).

Zygmunt Węclewski, w okresie lwowskim głównie hellenista, thumacz trzech wielkich tragików greckich, był pionierem badań nad poezją polsko-łacińską. Z ważniejszych rozpraw należy wymienić De Clementis Janicii vita, scripsis et editionibus (1864) oraz O poezjach Andrzeja Krzyckiego (1874). Ludwik Ćwikliński również zajmował się poezją łacińską Klemensa Janickiego, pozostawił serię artykułów (m.in. Klemens Janicki: poeta uwieńczony (1516-1543) z 1893 r., O wawrzynie doktorskim i poetyckim Klemensa Janickiego z 1919 r.), których ukoronowanie stanowi opracowana przez niego edycja twórczości tego poety w serii Polskiej Akademii Umiejętności: Corpus antiquissimorum poëtarum Poloniae-Latinorum (1930). Warta przypomnienia jest także pozycja Przyczynki do historii poezji polsko-łacińskiej w. XVI (1934). Bronisław Kruczkiewicz również podążył w kierunku wskazanym przez Ćwiklińskiego (literatura polsko-łacińska), wybrał jednak innych pisarzy. We wspomnianej serii PAU (Corpus antiquissimorum poëtarum ...) wydał dzieła humanistów Pawła z Krosna i Jana z Wiślicy (1887) oraz Pieśni Piotra Royzjusza (2 tomy) z imponującym wstępem liczącym 135 stron (ukazały się w 1900 r. jako Petrii Royzii Maurei Alcagnicensis Carmina). Ogłaszał także obszerne studia poświęcone tym autorom w „Rozprawach Wydziału Filologicznego AU” (1887 i 1898). Wymienione artykuły tych trzech autorów wytyczały następcom szlak w naukowej refleksji nad poezją polsko-łacińską.

Zainteresowania filologiczne dwóch innych profesorów, Jerzego Kowalskiego i (zwłaszcza) Ryszarda Ganszyńca, obejmowały bardziej rozległe zagadnienia związane z polską literaturą. Jerzy Kowalski, uczony drobnej postury, ale ogromnej energii, który współczesnych zadziwiał inteligencją, elokwencją, erudycją, błyskotliwością - według świadectwa Tymona Terleckiego: „człowiek o gigantycznej wiedzy i oszałamiającym tempie mówienia" ${ }^{3}$ - był bardziej łacinnikiem niż grecystą, ale oddał niebanalne usługi polonistyce jako badacz spuścizny Kopernika i Mickiewicza. Astronoma upamiętnił w monografii Kopernik jako filolog i poeta taciński (1924). Z dorobku Mickiewicza wybrał wykłady lozańskie, którym poświęcił kilka lat drobiazgowych studiów filologicznych. $Z$ zachowanych w teczce osobowej uczonego dokumentów (zdeponowanych w Państwowym Archiwum Obwodowym we Lwowie $\left.{ }^{4}\right)$ wynika, że korzystał w tym celu co najmniej dwukrotnie z całorocznych

3 T. Terlecki, Spotkania ze swoimi, Wrocław 1999, s. 366.

4 Державний архів Львівської області [dalej: DALO], fond 26, opis 5, sprawa 876 (teczka osobowa Jerzego Kowalskiego). 
urlopów naukowych (w roku akademickim 1923/1924, kiedy wyjechał do Lozanny ${ }^{5}$, oraz w roku 1926/19276). Dokonywane systematycznie odkrycia ogłaszał w kolejnych rozprawach i przyczynkach po polsku i po francusku: Nie znane wzmianki o A. Mickiewiczu w korespondencji Justa i Karoliny Olivierów (1925/1926), Czy zginie dla Polski? O wyktadach lozańskich Mickiewicza (1926), Note sur la première édition monographique des leçons de Mickiewicz à Lausanne (1926), Adam Mickiewicz à Lausanne (1839-40) (1927). Największym jednak osiągnięciem Kowalskiego okazał się polski przekład Mickiewiczowskich wykładów, zamieszczony w tomie VII dzieł wszystkich poety ${ }^{7}$. Został on wzbogacony przez translatora ogromnym wstępem, który można uznać za monografię, oraz stukilkunastostronicowym dodatkiem krytycznym.

Zarówno tłumaczenie, jak i doskonałe opracowanie filologiczne okrzyknięto rewelacją i majstersztykiem edytorstwa. „Kowalski dokonał przekładu jakby pod szept Mickiewicza - nie ukrywał podziwu Tadeusz Mikulski - z zasobów jego prozy utrwalonej w rozmowie i korespondencji, przerzucając całe złoża dokumentów, by wytropić słuszność lub prawdziwość użytego w przekładzie rzeczownika czy przymiotnika. Tak zostało wrócone słowu polskiemu dzieło Mickiewicza powiedziane z katedry lozańskiej w obcym języku" . Co ciekawe, opublikowana praca stanowiła jedynie skrót ogromnej całości: pełna wersja monografii Kowalskiego (wraz z dodatkowymi materiałami i notatkami) liczyła około 1500 stron?.

Kowalski był nie tylko wybitnym filologiem łacińskim i greckim. Objawił też swój talent jako literat. Wspólnie z żoną Anną z Chrzanowskich, pisarką, tworzyli bardzo poczytne w swoim czasie powieści: Catilina (1931), Mijaja nas (1932), Złota kula (1933), Gruce (1936). Publikował też ciekawe reportaże ze swoich zagranicznych podróży. Uważano go również za mistrza eseju, wytrawnego stylistę. Najpierw we Lwowie, później we Wrocławiu małżeństwo Kowalskich utrzymywało bliskie kontakty z polskimi pisarzami, szczególnie przyjaźniło się z Marią Dąbrowską.

Pora przyjrzeć się badaniom Ryszarda Ganszyńca, które łączą go z polonistyką. Nazywany słusznie człowiekiem-instytucją, dzięki niezmordowanej działalności popularyzatorskiej, organizacyjnej, edytorskiej i translatorskiej był chyba najbardziej wszechstronnym filologiem klasycznym w przedwojennej Polsce. Miał umysł

5 DALO, fond 26, opis 5, sprawa 876, k. 24 (Ministerstwo Wyznań Religijnych i Oświecenia Publicznego udziela J. Kowalskiemu urlopu naukowego w roku 1923/1924 na wyjazd do Lozanny, decyzją z 13 IX 1923 r.). Zob. też k. 30 (prośba J. Kowalskiego do Senatu UJK o zaliczkę na ten wyjazd, pismo z 25 IX 1923 r.).

6 Ibidem, k. 50 (decyzja Ministerstwa WRiOP z 19 VI 1926 r. o przyznaniu J. Kowalskiemu urlopu w roku 1926/1927).

7 Na edycję tego tomu, wchodzącego w skład tzw. Wydania Sejmowego, przyszło filologowi czekać aż do 1936 r. Z przechowanego w lwowskim archiwum listu do dziekana Wydziału Humanistycznego UJK z 19 V 1927 r. można wnioskować, że autor już wtedy sygnalizował przedłużające się procedury związane z tą publikacją: „Nie mając nadziei ogłosić rychło drukiem większej pracy mojej z powodów leżących w organizacji komitetu redakcyjnego, spodziewam się przecież [...] ogłosić kilka prac i przyczynków [...]". DALO, fond 26, opis 5, sprawa 876, k. 46.

8 T. Mikulski, Miniatury krytyczne, przedmowa W. Weintraub, Warszawa 1976, s. 51.

9 Zob. J. Starnawski, Sylwetki lwowskich historyków literatury, Łódź 1997, s. 184. 
o szerszych horyzontach niż jego koledzy. Obejmował swymi badaniami antyk, średniowiecze, renesans i barok. Zajmował się nie tylko literaturą, ale także bardzo szeroko rozumianą kulturą starożytnych - ich religiami, filozofią, etnologią, nawet historią medycyny. Prowadził studia językoznawcze. Jako mediewista i humanista eksplorował obszary wcześniej nieznane. Pisał i publikował bardzo dużo - po polsku, niemiec$\mathrm{ku}$, łacinie. Nic dziwnego, że lwowska wszechnica usilnie zabiegała o pozyskanie go na katedrę mimo młodego wieku, braku habilitacji (profesurę zwyczajną uzyskał w roku $1925^{10}$ ) oraz atmosfery skandalu, jaka towarzyszyła jego odejściu z Uniwersytetu Poznańskiego ${ }^{11}$.

Jedną z pierwszych prac, które poświęcił rodzimemu piśmiennictwu, była książka Brata Mikołaja z Polski pisma lekarskie (1920). Czytelnicy otrzymali studium o kulturze lekarskiej średniowiecza na przykładzie dorobku dominikanina krakowskiego, leczącego Leszka Czarnego i Gryfinę. Historyka literatury nie interesują jednak podręczniki medyczne, tylko poetycki traktat Antipocras (czyli Antihippocrates), który powstał między rokiem 1271 a $1278^{12}$ i miał być polemiką z naukami Hipokratesa. Praca Ganszyńca stanowi wyczerpujące kompendium wiedzy nie tylko o życiu, dokonaniach i poglądach na medycynę tytułowego bohatera, postaci w dwudziestoleciu międzywojennym niemal zapomnianej. Uczony odkrywa przed czytelnikiem także nieznanego pisarza, sumiennie wnika w tajniki jego warsztatu, przynosi skrupulatną analizę filologiczną jego tekstów, sięgającą aż po detale metryki wierszy.

Monografia Ganszyńcaujawniaimponujące metody badawcze uczonego, ,filologa-komparatysty - by posłużyć się trafnym określeniem Tadeusza Ulewicza - czującego się swobodnie na terenie każdej specjalności w ramach swojej epoki i rozważającego każdy szczegół na szerokim tle porównawczym, w oparciu o możliwie pełny zasób wiedzy o pisarzu, dziele, rodzaju literackim, czasach, w sumie - wszystkim, co tylko może posłużyć jako wskazówka lub informacja"13.

Za szczególnie cenne uważa się jego studia nad epistolografią polsko-łacińską, zwłaszcza miłosną, u progu renesansu oraz nad poezją polsko-łacińską średniowiecza i odrodzenia. W 1925 roku opracował i wydał Polskie listy miłosne dawnych czasów. Książka stanowi wyczerpujące opracowanie tej dziedziny piśmiennictwa. Zawiera informacje na temat poetyki, stylu i dziejów listu miłosnego od starożytności,

10 DALO, fond 26, opis 5, sprawa 370 (teczka osobowa Ryszarda Ganszyńca), k. 146 (mianowanie go profesorem zwyczajnym filologii klasycznej; pismo z 26 III 1925 r.).

${ }_{11}$ Chodzi o kilka spraw, do których zbadania powołano na Uniwersytecie Poznańskim komisję dyscyplinarną. Obszerne sprawozdania z tych posiedzeń (zob. DALO, fond 26, opis 5, sprawa 370, k. 9-37) przekazano wraz z innymi dokumentami władzom Uniwersytetu Jana Kazimierza. Powołana tam specjalna komisja do obsady katedry filologii klasycznej na posiedzeniu 16 X 1920 r., po dokładnym zapoznaniu się z aktami poznańskimi, podtrzymała decyzję o zatrudnieniu Ganszyńca, usprawiedliwiając na różne sposoby naganne postępowanie młodego wykładowcy (zob. DALO, fond 26, opis 5, sprawa 370, k. 41-42).

12 Wilhelm Bruchnalski ustalił datę powstania utworu na 1278 r. W. Bruchnalski, Lacińska i polska poezja w Polsce średniowiecznej [w:] Dzieje literatury pięknej w Polsce, praca zbiorowa, wyd. 2, cz. 1, Kraków 1935, s. 25.

13 T. Ulewicz, Ryszard Gansiniec i jego badania nad kultura polskiego średniowiecza i renesansu, „Pamiętnik Literacki” R. 49, 1958, z. 4, s. 652. 
następnie analityczny przegląd listów polsko-łacińskich z tak zwanego berlińskiego listownika, ponadto antologię tekstów zarówno w oryginale, jak i w przekładzie zaopatrzonym w solidny aparat krytyczny. Cenne dopełnienie tworzą studia o średniowiecznym ideale kobiecego piękna oraz o „stosunku listu średniowiecznego do renesansowego" (to ostatnie ukazało się też jako osobna pozycja pt. Epistolografia polsko-łacińska oraz jej stosunek do epistolografii humanistycznej, 1925). Uczony rozwijał swoje wywody w kolejnych artykułach: $\mathrm{Zu}$ den Tegernseer Liebesbriefen (1925), Polsko-łacińskie listy miłosne (1926), Analekta do „Listów milosnych” (1929), Listownik Jana Ursinusa (1952).

Prace nad poezją polsko-łacińską można podzielić na ogólne, poświęcone temu rodzajowi liryki, jak i na studia o poszczególnych pisarzach. Łącznie obejmują ponad 40 pozycji (nie licząc artykułów popularnonaukowych). Osiągnięcia Ganszyńca w tej dziedziny były pionierskie, przedzierał się niejako przez tereny dziewicze, wówczas jeszcze przez filologów nieuprawiane. Charakterystyce zjawiska literackiego czy też gatunku poświęcił rozprawy: Lacińsko-polskie poezje XV wieku (1924), Echa pieśni goliardowej w Polsce (1930), Średniowieczne „Computi” polsko-łacińskie (1935), Pieśni wagantów (1937), Hymny chrześcijańskie (1937). Zainteresowania pieśnią filolog nie ograniczał do twórczości literackiej - interesował się śpiewem, znał się na tym, prowadził bowiem wśród studentów chór łaciński. Przypominanie pieśni greckich i łacińskich ${ }^{14}$ stanowiło jeden $\mathrm{z}$ wielu elementów popularyzowania przez Ganszyńca antyku w środowisku lwowskim.

Z poetów polsko-łacińskich wiele uwagi poświęcił uczony Andrzejowi Krzyckiemu. Drobne artykuły dotyczące tego pisarza wydawał jako criciana (w „Eos” 1921, w „Pamiętniku Literackim” 1923-1926, później w „Przeglądzie Klasycznym” 1937). Te ustalenia tak dalece pogłębiły wiedzę o Krzyckim, że opracowania wcześniejszych badaczy straciły aktualność. Wydał też księgę hymnów Jana Dantyszka, którą opatrzył filologicznym wstępem (1934). Pisał o Epitafium Zawiszy Czarnego autorstwa Adama Świnki (1924/1925). Z późniejszych poetów dwujęzycznych nieco więcej absorbował go Sebastian Klonowic, szczególnie jego związki z antykiem: De Sebastiano Acerno Vergilii admiratore (1930/1931), De Sebastiani Acerni lectione Hesiodea. Ibid. (1932/1933). Pięć rozpraw poświęcił obfitej twórczości Macieja Sarbiewskiego, którego dzieła osadził w kontekście europejskiego baroku łacińskiego (prace z lat 1931-1934). W 1934 roku wydał też Silviludia Sarbiewskiego.

Znaczące osiągnięcie związane z polskim piśmiennictwem stanowiły także studia nad Mikołajem Kopernikiem. Pierwszą rozprawę ogłosił Ganszyniec już w 1924 roku (Mikołaj Kopernik jako lekarz), ale do postaci astronoma wrócił dopiero po wojnie (Rheticus jako wydawca Kopernika z 1952 r. oraz Rzymska profesura Kopernika z 1957 r., w której obalił ten popularny mit o astronomie). Najcenniejsza jednak okazała się redakcja łacińskiej wersji pism Kopernika (1953), pozwoliła bowiem rozstrzygnąć, które teksty są podstawowe (w tym słynne $O$ obrotach sfer niebieskich).

14 O tym, jak wysoko Ganszyniec cenił rolę śpiewu, świadczą jego rozprawy: Śpiew poezyj horacjańskich w szkole (Lwów 1935) oraz Pieśn tacińska w szkole, czyli o rehumanizacji filologii klasycznej (Lwów 1937). 
Na szczególną uwagę zasłużył sobie Gall Anonim. W 1923 roku ukazały się Przyczynki do krytyki tekstu Kroniki Galla, w 1924 roku In Galli Chronicon animadversiones criticae, natomiast w 1958, tuż po śmierci uczonego, obszerne studium Liryka Galla Anonima. Najstarszej polskiej kronice poświęcał też Ganszyniec całe cykle wykładów. Interesował się również kroniką Wincentego Kadłubka.

W powojennej bibliografii odrębny zbiorek tworzą prace narosłe wokół legendy Piotra Włostowica - wszystkie z lat 1951-1952: Średniowieczne poematy o Piotrze Wtostowicu, Gesta Piotrkonis, Autor kroniki Piotra komesa, Tragedia Petri Comitis. Obiektem wieloletniej filologicznej, ale i historycznej eksploracji okazał się również poznański nagrobek Bolesława Chrobrego, któremu Ganszyniec poświęcił cykl studiów monograficznych: Napis nagrobny Bolestawa Chrobrego (1936), Grobowiec Bolestawa Chrobrego (1949), Nagrobek Bolesława Wielkiego (1951). Uczony ustalił czas powstania grobowca oraz epitafium łacińskiego na lata 40. XIV wieku.

Jeszcze jeden teren filologicznej penetracji stanowiły poetyki średniowieczne. „[Ganszyniec] prowadził [...] szczegółowe badania źródłowe nad poetyką i metryką wieków średnich. Owocem tych zainteresowań jest wydanie szeregu wierszowanych łacińskich traktatów gramatycznych zawierających obok wiadomości z gramatyki również zrąb informacji z zakresu poetyki. Traktaty te stanowiły rodzaj podręczników szkolnych, z których uczyła się młodzież z Akademii Krakowskiej"15. Chodzi tutaj przede wszystkim o publikowane po drugiej wojnie Massa gramatice $i$,,Metrificale" Marka z Opatowca. Zarówno ta praca, jak i studia o traktatach gramatycznych XIV i XV wieku to - zdaniem Tadeusza Ulewicza - dzieła „o najwyższym ciężarze gatunkowym", bo odsłaniają zupełnie nowe obszary w badaniach nad kulturą umysłową polskiego średniowiecza: ,[...] ostatnia, a zarazem bodaj czy nie najważniejsza, pośmiertna już książka uczonego stawia nas na terenie literackich podręczników uniwersyteckich używanych w Akademii Krakowskiej jeszcze za czasów Kazimierza Wielkiego (tak!) i później za Władysława Jagiełły, a zatem dzieł kształtujących jak najbardziej bezpośrednio cały w ogóle kierunek oraz typ umysłowej i literackiej kultury naszej ówczesnej inteligencji”" ${ }^{16}$.

W roli językoznawcy występował Ganszyniec wielokrotnie. Nie tylko ze względu na bezustanne niemal obcowanie z łaciną i greką, lecz także jako badacz początków polskiej ortografii. W 1932 roku ogłosił artykuł O ortografii Jakuba Parkosza. W formie popularnonaukowej przedstawił historię alfabetu (Dzieje naszego abecadła, 1935). Bardziej obszerną pozycją jest opracowanie dziejów polskiego językoznawstwa od średniowiecza po współczesność. Stanowi ona duży rozdział w książce Jakuba Handla Dzieje językoznawstwa (1935). Znakomita znajomość łaciny zdecydowała o współudziale Ganszyńca w trójjęzycznej edycji Psałterza floriańskiego, w którym opracował właśnie część łacińską (1939), a wcześniej w przygotowaniu tekstu Modlitewnika Władysława Warneńczyka (1928) - oba ukazały się nakładem Wydawnictwa Ossolineum we Lwowie dzięki staraniom jego dyrektora Ludwika Bernackiego.

15 R. Turasiewicz, Ryszard Gansiniec [w:] Uniwersytet Jagielloński. Złota Księga Wydziału Filologicznego, red. J. Michalik, W. Walecki, Kraków 2000, s. 396.

16 T. Ulewicz, op. cit., s. 661. 
Powyższy przegląd polonistycznych zasług Ryszard Ganszyńca nie wyczerpuje długiej listy tematów. Można by do niej dopisać zgoła odmienną tematycznie, bo wynikającą z jego zamiłowania do Śląska, rozprawę Wklad czolowych przedstawicieli ziemi śląskiej w ksztattowanie się myśli poznawczej i literatury polskiego odrodzenia (1956). Jako dydaktyk poświęcał niektóre cykle wykładów i ćwiczeń polskiej literaturze (np. Kronika tzw. Galla jako pomnik literacki, Rytmika Kroniki Galla, Kronika Wincentego Kadtubka jako pomnik literacki, Ćwiczenia krytyki tekstowej nad tzw. Gallem i Wincentym Kadlubkiem czy Ortografia Jakuba, syna Parkosza, ze wstępem do dziejów ortografii).

Kierownik trzeciej katedry klasycznej w międzywojennym Lwowie, Stanisław Witkowski, wyświadczył stosunkowo małą przysługę polonistyce, ale i on zajmował się pisarzami polsko-łacińskimi. Przed rokiem 1920 ogłosił główne prace: Jan z Wiślicy. Jego życie i pisma (1891) oraz Echa klasyczne u Mikołaja Sepa Szarzyńskiego (1916).

Spośród filologów nowożytnych najwięcej polska literatura zawdzięcza romaniście Edwardowi Porębowiczowi, toteż od przedstawicieli lwowskiej romanistyki wypada zacząć opis dokonań. Zanim utworzono we Lwowie osobną katedrę, ujawnił się już na nią kandydat z zamiłowania w osobie Maksymiliana Kawczyńskiego. Habilitowany w 1884 roku z filologii germańskiej, następnie w 1887 roku z filologii romańskiej, daremnie czekał na objęcie własnej katedry, toteż w 1890 roku przeniósł się na Uniwersytet Jagielloński. Naukowe zainteresowania literaturą polską ograniczył do III części Dziadów Mickiewicza, czego dowodzą dwie interesujące rozprawki komparatystyczne: Adama Mickiewicza „Dziadów” część trzecia w stosunku do romantyzmu francuskiego (1893) oraz Konrad z „Dziadów” w poezji francuskiej (1898).

Katedrę filologii romańskiej erygowano we Lwowie dopiero w roku 1897, by w 1899 na długo powierzyć ją Edwardowi Porębowiczowi. Lata Porębowicza (do 1931 r.) wyznaczają złoty okres lwowskiej romanistyki. W roku 1922 utworzono oddzielną katedrę filologii francuskiej, którą objął Zygmunt Czerny - uczeń Porębowicza. Po przejściu mistrza na emeryturę pojawiły się problemy z obsadą katedry romanistyki. Do wybuchu wojny w zastępstwie pełnili funkcje kierowników Kazimierz Jarecki (bardzo zdolny uczeń Porębowicza), Jerzy Kuryłowicz (światowej sławy językoznawca) oraz Zygmunt Czerny.

O Edwardzie Porębowiczu bez przesady można powiedzieć, że należał do najwybitniejszych uczonych swojej epoki. Nadzwyczaj staranne i wszechstronne wykształcenie, otrzymane w Krakowie u najlepszych filologów, a dopełnione w słynnych uczelniach zagranicznych w Berlinie, Monachium, Montpellier, Barcelonie, Florencji, Wiedniu (tam uzyskał doktorat) i Paryżu, monstrualne wręcz oczytanie w niemal wszystkich literaturach europejskich, wyjątkowa łatwość opanowywania wielu języków, wybitny talent badacza tekstu połączony z talentem poetyckim, do tego niezwykła wrażliwość na słowo i dar urzekającego nim operowania - wszystko to czyniło z Porębowicza filologa o nieograniczonych niemal możliwościach badawczych. Autor monumentalnych monografii wszystkich literatur romańskich, mistrz przekładu z języków nowożytnych i dawnych: starofrancuskich, prowansalskich, gaskońskiego, katalońskiego, hiszpańskiego, portugalskiego, francuskiego, włoskiego, 
także angielskiego, niemieckiego, duńskiego, irlandzkiego, norweskiego, szwedzkiego, rosyjskiego - przetłumaczył dla Polaków Don Juana Byrona i Boska komedie Dantego, ale też niezliczone wiersze poetów całej Europy. Tytan pracy potrafił także poświęcić wiele czasu na wnikliwe studia nad literaturą polską.

Polonistom szczególnie bliskie były znakomite badania komparatystyczne, którymi Porębowicz obejmował barok, poezję wielkich romantyków oraz lirykę młodopolską. „Każda z tych prac jest stale żywotna, a prawie każda znaczy w swoim zakresie jakiś punkt zwrotny"17 - przyznawał Wacław Borowy. Pisarzy przedrozbiorowych dotyczą artykuł Źródta romansu artystycznego ww. XVIII (1893), rozprawa Sebastian Grabowiecki i jego wzory (1894) i przede wszystkim monografia Andrzej Morsztyn, przedstawiciel baroku w poezji polskiej (1894). W studium o Grabowieckim wykazał filolog wielki talent poetycki bohatera, ale zmienił dotychczasowe sądy na temat rzekomej oryginalności jego twórczości, wskazując liczne zapożyczenia z tomiku mało znanego włoskiego poety Gabriela Fiammy.

Praca o Morsztynie okazała się przełomowa z kilku powodów - nie tylko dlatego, że po raz pierwszy w Polsce pojedynczy poeta doczekał się takiego opracowania, ale także ze względu na penetrację epoki dotąd mało znanej i mało badanej. W rozprawie o Morsztynie Porębowicz jako pierwszy wprowadził termin „barok” na określenie epoki literackiej. Dotąd wiek XVII nazywano lekceważąco czasami panegiryzmu i makaronizmu. Uczony podał dokładną definicję baroku oraz jej uzasadnienie w sztukach plastycznych. Borowy nie krył zachwytu: „Definicję, dalej, uzupełniała analiza elementów stylistycznych, która nie tylko prześcigała wszystko, co krytyka polska posiadała w tym zakresie dawniej, ale i na czas długi jeszcze miała pozostać w niej unikatem. $\mathrm{Z}$ opisem łączył się rodowód zjawisk stylu barokowego o zasięgu terytorialnym i historycznym znowu u nas przedtem niesłychanym. Autor swobodnie się obracał zarówno w literaturze rzymskiej (i to wszystkich okresów), jak wśród latynistów humanistycznych, jak w poezji szesnasto- i siedemnastowiecznej (i to nie tylko krajów romańskich, ale i Niemiec, i Anglii)"18.

Morsztyn Porębowicza jawi się na takim tle w sposób nowatorski. Obalając wcześniejsze sądy (np. Adama Bełcikowskiego) o rzekomej oryginalności i genialnej wprost pomysłowości poety, filolog bez trudu wykazał, że przerabiał on bez żenady motywy upowszechnione w literaturach zachodnich, chociaż czynił to $\mathrm{z}$ wirtuozerią. I właśnie w tym mistrzowskim operowaniu formą upatrywał Porębowicz kunszt poetycki Morsztyna. Ustalenia Porębowicza okazały się zasadnicze i obowiązują do dziś.

Badania poświęcone największym polskim romantykom zachowały w znacznym stopniu charakter komparatystyczny. Mickiewicza dotyczy Urywek pierwszego brulionu „Pana Tadeusza” (1893) oraz kilka prac ogłoszonych w roku jubileuszowym (1898): Przyczynek do pojęcia „romantyczność” u Mickiewicza, Stówko o motywie ballady „Powrót taty”, Gdzie jest źródto wiary Mickiewicza w godność proroczq

17 W. Borowy, Edward Porębowicz jako krytyk i jako badacz literatury polskiej, „Przegląd Współczesny" R. 12, 1933, t. 44, nr 131, s. 345.

18 Ibidem, s. 346. 
poety? W ostatnim artykule wykazał Porębowicz inspiracje Mickiewicza filozofią niemiecką. Do Słowackiego powracał trzykrotnie: w artykule Jeszcze „Beatrix Cenci” (1896), publikując na łamach „Chimery” nieznane fragmenty Króla-Ducha (1901) oraz ogłaszając Glosę do „Genezis z Ducha” (1917). Wreszcie Krasińskiemu dedykował rozprawę Triady Zygmunta Krasińskiego (1900), rzecz o Nie-Boskiej komedii, Irydionie oraz Niedokończonym poemacie. To kolejna przełomowa, bardzo ważna rozprawa ze względu na przekonującą rekonstrukcję portretu filozoficznego poety, którego ideologia stanowi pewną sumę zarówno poglądów wielu myślicieli romantycznych (w tym niemieckich), jak i wypadkową dawniejszych wierzeń oraz teorii. Porębowicz precyzyjnie wyodrębnia części składowe tej skomplikowanej duchowej struktury. Na koncepcji romanisty opierał się później Juliusz Kleiner w najsłynniejszej przedwojennej monografii o Krasińskim.

Bardzo postępowe, zdecydowanie wyprzedzające swoją epokę poglądy na temat współczesnej mu literatury ogłosił Porębowicz w studium Poezja polska nowego stulecia. Cz. I. Teoria (1902). Zdobył się w nim autor na wnikliwe, krytyczne zbadanie świeżych jeszcze, trwających i narastających prądów, które z czasem miały ukształtować literackie oblicze Młodej Polski. Wobec prężnego i atrakcyjnego dekadentyzmu filolog wskazywał sposoby przezwyciężenia destrukcyjnego nurtu, nie umniejszając przy tym artystycznych wartości wierszy. Prorocza okazała się jego opinia o Przybyszewskim, wygłoszona w czasie, kiedy autor Confiteoru zaczynał dopiero odnosić największe sukcesy. Obnażał wtórność, naśladownictwo, brak oryginalności jego utworów, wykazywał zapożyczenia raz z repertuaru romantyków, kiedy indziej $\mathrm{z}$ baroku, dostrzegał ubóstwo motywów powielanych wielokrotnie w dramatach. Skandalizująca biografia i głośna reklama przeciwko niskiej wartości pisarstwa oto demon Przybyszewskiego, bożyszcze młodopolskiej bohemy, które - jak trafnie przewidywał Porębowicz - nie oparło się próbie czasu.

O doniosłości omawianej rozprawy stanowiło użycie po raz pierwszy przez Porębowicza terminu „,neoromantyzm” na oznaczenie współczesnej mu epoki i wprowadzenie tej nazwy na kilka dziesięcioleci do literatury naukowej (czego przykładem jest monografia Juliana Krzyżanowskiego). Wykazując rozliczne filiacje rodzimej poezji z liryką Maeterlincka, Verlaine'a, symbolistów francuskich, dostrzegał przenikliwy badacz silne bodźce, jakich dostarczała francuskim poetom romantyczna filozofia niemiecka, zwłaszcza poglądy idealistyczne. Podobieństw do romantyzmu, rozmaitych kontynuacji odnajdował we współczesnej mu literaturze polskiej aż nazbyt wiele. W Młodej Polsce widział odrodzenie romantyzmu, który będąc epoką silnych osobowości, znaczących przełomów, wprowadzeniem ludzkości w czasy nowożytne, trwał zbyt krótko, dlatego po pewnym czasie stało się naturalne, że musiał znaleźć jeszcze jakieś ujście i nadal żyć drugim życiem.

Współcześnie, po przeszło stu latach od ogłoszenia tych rewelacji, nie uświadamiamy sobie, jak niezwykłym zjawiskiem była naukowa twórczość Porębowicza: „[...] była zjawiskiem [...] wielkiej wagi - konstatuje Jan Prokop - nie tylko na tle swej epoki, którą wzbogaciła o całe obszary spraw i problemów, dotąd znajdujących się tylko na marginesach świadomości literackiej lub w ogóle w niej nieobecnych, 
a bez których Młoda Polska byłaby nieporównanie uboższa i jednostronna"19. Podobnie „barok polski jako część wielkiego i bogatego zjawiska europejskiego - do dziś jest przedmiotem zainteresowania nie tylko uczonych, lecz także artystów"20 w znacznym stopniu dzięki badaniom Porębowicza.

Jeszcze jeden rodzaj naukowej aktywności wiąże genialnego romanistę z polonistyką. Chodzi o liczne recenzje zarówno zagranicznych prac naukowych, jak i polskich. Dzięki temu przybliżał czytelnikom w kraju aktualne zdobycze literaturoznawstwa francuskiego czy angielskiego, na bieżąco też rekomendował (niekiedy krytykował) owoce pracy nad polską literaturą, na przykład Ignacego Matuszewskiego Stowackiego i nowa sztuke, Piotra Chmielowskiego Najnowsze prądy w poezji naszej. Arcyrecenzją nazwał Jerzy Starnawski komentarz do Żywych kamieni Wacława Berenta.

Kazimierz Jarecki, który po przejściu Porębowicza na emeryturę w zastępstwie pełnił obowiązki kierownika katedry, zostawił całkiem pokaźny dorobek związany z polską literaturą. Obejmuje on grupę artykułów poświęconych twórczości Słowackiego, którą otwiera obszerna rozprawa Juliusz Stowacki i poemat ,W Szwajcarii” " (1901). Romanista podjął się w niej analizy utworu pod kątem psychologicznym, ustalił datę jego powstania na rok 1835, obalił hipotezę o wpływie miłości do Marii Wodzińskiej. Wkrótce ukazały się kolejne publikacje, między innymi Do genezy „Mazepy” (1903), Znaczenie i idea „Króla-Ducha” Stowackiego (1903), Kiedy powstat ,Wacław” Stowackiego? (1903), Stowackiego „Beatrix Cenci” (1904), Testament mój (1909). W 1903 roku ukazał się też drukiem odczyt Juliusz Stowacki, w którym autor porównywał go z Mickiewiczem, wykazując przy tym przyczyny mniejszej popularności drugiego wieszcza za życia („niewspółczesność z epoką”) oraz większego niż rywal wpływu na czytelników doby modernizmu.

Z okazji jubileuszu Konopnickiej dedykował jej Jarecki studium Twórczość poetycka Marii Konopnickiej (1902). Interesował się mesjanizmem (Idee historiozoficzne Woronicza a mesjanizm polski, 1904) i postacią Andrzeja Towiańskiego. W broszurze Kilka uwag z powodu książki p. Mazurkiewicza ${ }^{21}$ (1903) starał się obalić prezentowane tam negatywne sądy o mistyku i ukazać jego postać w jak najkorzystniejszym świetle. Nic dziwnego, że osoby z kręgu Władysława Mickiewicza entuzjastycznie zrecenzowały owo dziełko ${ }^{22}$. Kolejny artykuł (Śp. Karol Baykowski i towianizm, 1904) już nie gloryfikował Towiańskiego. Kilka prac poświęcił Szymonowi i Bartłomiejowi Zimorowicom, badając wybrane motywy w ich twórczości: Kilka uwag o utworach Szymona Zimorowica (1903), Spór o dwu Zimorowiców ${ }^{23}$

19 J. Prokop, Edward Porębowicz [w:] Obraz literatury polskiej XIX i XX wieku, red. K. Wyka et al., seria 5: Literatura okresu Młodej Polski, t. IV, Kraków 1977, s. 259.

20 Ibidem, s. 259.

21 Chodzi o książkę Jana Mazurkiewicza Andrzej Towiański. Studium psychologiczne (1901).

22 Mowa tu o korespondencji między Attilio Begeyem a Władysławem Mickiewiczem. Zob. M. Bersano-Begey, Korespondencja A. B-a z W-tem Mickiewiczem, „Blok Notes Muzeum Literatury im. A. Mickiewicza" 1983, s. 53, 57.

${ }^{23} \mathrm{~W}$ tej rozprawce Jarecki polemizuje z poglądem Kornelego Juliusza Hecka, który dowodził wspólnego autorstwa Roksolanek i Sielanek nowych ruskich. Zob. Stownik badaczy literatury polskiej, red. J. Starnawski, t. III, Łódź 2000, s. 159-160. 
(1904), Hieronima Morsztyna „Światowa rozkosz” a „Roksolanki” Sz. Zimorowica. Z innych ważniejszych publikacji warto przypomnieć: Motyw „miłości i śmierci”, w poezji polskiej (1907), Pierwsze polskie thumaczenie z Anakreonta (1908), Polskie tłumaczenia i przeróbki z Anakreonta (1910) oraz poświęcone pobytowi Mickiewicza w Konstantynopolu Braterstwo polsko-tureckie (1915). Trafnie podsumował ten etap pracy naukowej Jareckiego Stanisław Wasylewski: „[...] rokował piękne nadzieje. Patrzył szerzej i dalej niż przeciętnego typu humanista. Poświęcił się młodej wtedy literaturze porównawczej $[\ldots]^{\prime 24}$.

Zygmunt Czerny sporadycznie nawiązywał do pisarzy polskich w pracach komparatystycznych (np. Krasiński w literaturze francuskiej - z 1912 r.).

Dzieje germanistyki lwowskiej przyjęło się rozpoczynać od Augusta Sauera, który zainaugurował je wykładami w 1879 roku jako zastępca profesora. W 1884 roku powołano do Lwowa z Grazu Richarda Marię Wernera. Jako kierownik katedry ustalił Werner jej losy na blisko 30 lat (do 1912 r.). Dał się poznać nie tylko jako wybitny uczony, ale także jako zasłużony dydaktyk, który wśród swoich uczniów wykształcił również grono wybitnych polonistów: Juliusza Kleinera, Manfreda Kridla, Konstantego Wojciechowskiego, Kazimierza Kolbuszewskiego. Od 1912 roku aż do wybuchu II wojny światowej niezmordowanie kierował katedrą Wiktor Dollmayr. W pierwszym okresie jego profesury wspomagał go wykładami zdolny docent Emil Petzold (1915-1921).

Richarda Marię Wernera łączyły serdeczne stosunki z Romanem Pilatem, wybitnym polskim literaturoznawcą, kierownikiem jedynej (do 1903 r.) katedry języka i literatury polskiej na Uniwersytecie Lwowskim. Ma rację Jerzy Starnawski, przypisując wpływom Pilata zainteresowanie Wernera polskimi pisarzami, głównie Mickiewiczem ${ }^{25}$. Przemawiały też za tym fakty: Pilat był redaktorem „Pamiętnika Towarzystwa Literackiego im. A. Mickiewicza" i od początku powstania czasopisma (1887) włączył Wernera do grona autorów. W kolejnych edycjach „Pamiętnika” Werner ogłosił kilka przyczynków (Wiersz Uhlanda do Mickiewicza, 1887; Wspomnienie Alfreda Meissnera o Mickiewiczu, 1887; Wiersz przypisywany Mickiewiczowi, 1888; Niemiecki nekrolog Mickiewicza, 1891) oraz rozprawkę Parę uwag o motywie zasadniczym „Alpuhary” (1898), w której dowodził, że pewną inspiracją do stworzenia ballady z Konrada Wallenroda mogła być nowela Heinricha von Kleista Die Verlobung in St. Domingo. Większość drobiazgowych odkryć dotyczących Mickiewicza zebrał i powtórzył w jednej z najważniejszych swoich książek Lyrik und Lyriker (1890), dzięki czemu dowiedzieli się o nich przedstawiciele europejskiej humanistyki.

Emil Petzold, przez wiele lat nauczyciel gimnazjalny (m.in. Juliusza Kleinera), właśnie w tym okresie gromadził swój polskojęzyczny dorobek. W historii literatury polskiej najbardziej upodobał sobie romantyzm, ze szczególnym uprzywilejowaniem twórczości Mickiewicza. Dowodzą tego: komparatystyczny Przyczynek do genezy „Romantyczności” Mickiewicza (1902), wykazujący wpływ poglądów Herdera

24 S. Wasylewski, Pożyczanie książek do domu [w:] Zakład imienia Ossolińskich 1827-1956 $w$ dziesięciolecie działalności we Wrocławiu, red. nauk. W. Floryan, Wrocław 1956, s. 110.

25 Zob. J. Starnawski, op. cit., s. 42. 
i Friedricha Schlegla na programową balladę, ogłoszone w tym samym roku Motywy Mickiewiczowskie (1902), ważna rozprawa $O$ „Czatach” Mickiewicza (1905), którą Kleiner uznał za wzorcową analizę, a także komparatystyczne studia polsko-niemieckie: Reminiscencje z Tiecka w „Dziadach” (1906) i Ballada Mickiewicza a Goethego (1910), uznawana za jedną z najlepszych pozycji w bibliografii autora. W polonistycznym dorobku Petzolda można jeszcze odnaleźć dwie nieduże publikacje: Czy reminiscencje z Novalisa? oraz „W sprawie pokoju wieczystego. Projekt filozoficzny" - a Polska (Z okazji artykutu Piotra Chmielowskiego).

Juliusz Kleiner pisał w nekrologu:

Literaturę polską obdarzył studiami o „Motywach Mickiewiczowskich” w związku z romantyką niemiecką, drukowanymi w „Pamiętniku Literackim”, mistrzowską analizą ballady Mickiewicza „Czaty” (ogłoszoną w Sprawozdaniu gimn. IV we Lwowie 1905, a potem wydaną osobno) i rozprawą o „Balladzie Goethego i Mickiewicza” (,Przewodnik Naukowy i Literacki” 1910), przynoszącą wyniki zasadnicze zarówno w zakresie badania ballady, jak co do typu twórczości obu wielkich poetów. Rozprawę tę znać powinien każdy badacz literatury naszej ${ }^{26}$.

Specjalną katedrę anglistyki utworzono we Lwowie w roku 1922. Wykłady powierzono wówczas świeżo habilitowanemu Władysławowi Tarnawskiemu, który początkowo prowadził je jako zastępca profesora, by od stycznia 1924 r. jako profesor nadzwyczajny objąć kierownictwo (do 1934 r., później w latach 1937-1939 i w czasie sowieckiej okupacji Lwowa). Tarnawski zasłynął jako wybitny znawca twórczości Szekspira, tłumacz wielu jego dzieł, autor imponującej rozmiarami $\mathrm{Hi}$ storii literatury angielskiej.

Związki uczonego z polonistyką są wielorakie - najpierw jako byłego nauczyciela gimnazjalnego w Przemyślu, gdzie przez 10 lat uczył między innymi języka polskiego (1914-1924), następnie dzięki znakomitym przekładom, które przybliżały polskim miłośnikom literatury arcydzieła angielskie. Wreszcie - idąc śladem innych filologów nowożytnych - umocnił te związki jako badacz oraz interpretator tekstu, utalentowany komparatysta. Przy okazji przekładów Szekspirowskich ogłosił artykuł o Kleopatrze Norwida oraz o Szekspirze Kasprowicza (1929). Studiował recepcję wybranych pisarzy ( $Z$ dziejów Ossjana w Polsce, 1927), interesował się angielskimi przekładami Sienkiewicza (1933). Wzbogacił też bibliografię przedmiotową Mickiewicza, zabierając głos w sprawie III części Dziadów (Konrad a ludzie i naród, 1934).

W latach 1936-1939 przerzucił Tarnawski kolejny most między anglistyką a polonistyką za sprawą stałej współpracy z periodykiem „Nowe Książki”. Publikował tu krótkie recenzje wszelkich nowych przekładów dzieł angielskich i amerykańskich pojawiających się właśnie na polskim rynku. Odgrywał wówczas rolę niejako dyżurnego recenzenta i popularyzatora twórczości anglojęzycznej. Autor blisko 170 księgarskich rekomendacji ${ }^{27}$ oddał sporą przysługę nie tylko studentom polonistom. Niekiedy wcielał się $\mathrm{w}$ rolę historyka literatury polskiej jako autor publicznych wykładów. Do najwcześniejszych należał odczyt Dwie monografie o Stowackim,

\footnotetext{
26 J. Kleiner, Emil Petzold, „Słowo Polskie” R. 36, 1932, nr 198, s. 6.
}

27 Zob. J. Starnawski, op. cit., s. 241. 
wygłoszony w Przemyślu w jubileuszowym roku wieszcza (7 VI 1909). Porównywał wtedy Tarnawski wartość książki Antoniego Małeckiego i Józefa Tretiaka, pierwszeństwo przyznając Małeckiemu. Prawdopodobnie ostatnim wystąpieniem popularyzującym narodową literaturę $\mathrm{w}$ rodzinnym mieście był wykład poprowadzony 26 czerwca 1924 roku, poświęcony ,pismom zapomnianym i niewydanym Sienkiewicza" na podstawie prac Ignacego Chrzanowskiego.

Katedrę filologii ruskiej (bo tak wówczas nazywano język ukraiński) utworzono na Uniwersytecie Jana Kazimierza w 1925 roku jako rodzaj rekompensaty dla studentów ukraińskich w miejsce rozwiązanego w tym samym roku nielegalnego Tajnego Uniwersytetu Ukraińskiego. Od początku jej istnienia do wybuchu wojny kierownikiem pozostawał polski profesor Jan Janów. Jako slawista, ale też polonista przyczynił się w niemałym stopniu do poszerzenia wiedzy o polskich pisarzach.

Reprezentował on typ filologa zajmującego się równolegle językoznawstwem oraz historią literatury. Sumiennie analizował zabytki polskiego piśmiennictwa średniowiecznego oraz pierwszej połowy XVI wieku, badał ich recepcję na Rusi. Wykazał, że pierwszą polską książką nie był Raj duszny Biernata z Lublina (1513), jak dotąd sądzono, ale Historyja umęczenia Pana Jezusa wydana u Kaspra Hochfedera (przed 1508 r.). Opublikował też i opracował orientalną legendę o Barlaamie i Jozafacie w przekładzie Sebastiana Piskorskiego, tropiąc jej obecność w różnych kulturach. Wspomnianej legendy dotyczą następujące prace: Romans o Barlaamie i Jozefacie w przeróbce Skargi, Baraniewicza i Lichoniewicza (1923), Do dziejów „Historii Barlaama i Jozefata” w przektadzie Seb. Piskorskiego (XVII w.) (1933), Do dziejów „Historii Barlaama” w przekładzie rumuńskim (1933). Ogłaszał także rozprawy komparatystyczne, między innymi Wplywy polskie na literaturę Rusi XVIII w. (przeglad badań dotychczasowych) z 1934 roku. Wiele artykułów i przyczynków poświęcił Biblii Królowej Zofii, Gesta Romanorum, Rozmowom Mistrza ze Śmiercia, Żywotowi Pana Jezu Krysta. Interesował się twórczością Mikołaja Reja, Jakuba Wujka, Piotra Skargi. Badał też przekłady literatury polskiej na język ukraiński, o czym świadczą następujące prace: Ttumaczenia ruskie z „Postylli” M. Reja w ewangeliarzach kaznodziejskich XVI i XVII w. (1929), O przekładzie „Wieczności piekielnej” na język polski i ruski (1929), Legendarno-apokryficzne opowieści ruskie o męce Chrystusa (z uwzględnieniem zabytków staropolskich) (1931).

Rzadziej sięgał po teksty z późniejszych epok. W 1935 roku na Zjeździe im. Ignacego Krasickiego we Lwowie przedstawił referat Dzieła Krasickiego na Rusi (opublikowany w postaci obszernej rozprawy w 1936 r.). Niewielki tekst Przyczynek do „, lafiryndy” (1932) dotyczy między innymi pisarstwa Jędrzeja Śniadeckiego. Badał też kolędę staropolską (przyczynki z 1937 i 1938 r.).

Rola, jaką odegrał Jan Janów w rozwijaniu lwowskiej polonistyki, widoczna jest bezpośrednio $\mathrm{w}$ dziedzinie dydaktyki. Co najmniej przez siedem lat powierzano mu zajęcia na filologii polskiej. Prowadził tam między innymi wykład o apokryfach w Polsce i na Rusi (1928/1929 oraz 1934/1935), dialektologię polską (1935/1936), ponadto ćwiczenia polonistyczne w czytaniu i objaśnianiu zabytków staro-cerkiewno-słowiańskich, staropolskich i polskich dialektycznych (np. 1928/1929), a nawet 
proseminarium języka polskiego (z asystentem Stanisławem Bąkiem, 1926/1927) oraz seminarium niższe języka polskiego (1927/1928 i 1935/1936).

Dokonania lwowskich filologów spoza katedr polonistycznych na rzecz nauki o polskiej literaturze wypadają imponująco. Ogłaszane prace - od małych przyczynków po pokaźne książki - wskazują na dużą różnorodność podejmowanych tematów. Specjaliści w zakresie obcych literatur i języków nie unikali problemów, które często dla samych polonistów okazywały się albo zbyt zawiłe, albo z jakichś powodów niewygodne. Swoimi odkrywczymi sądami nierzadko wytyczali nowe kierunki w badaniach twórczości danego pisarza czy zjawiska ważnego dla epoki. Osiągnięcia najwybitniejszych - Ryszarda Ganszyńca czy Edwarda Porębowicza - można uznać za kamienie milowe w rozwoju nowoczesnego literaturoznawstwa. Dotyczy to przede wszystkim rozległych badań Ganszyńca nad poezją polsko-łacińską, zwłaszcza miłosną, rozpraw o poetyce i metryce średniowiecznej oraz o najdawniejszych traktatach ortograficznych - te studia mają charakter pionierski. Podobnie w dorobku Porębowicza monografia o Janie Andrzeju Morsztynie jest pierwszą tego typu publikacją, w dodatku do dziś aktualną. W poglądach na temat pisarzy młodopolskich znakomity romanista wyprzedził epokę, jego diagnozy zweryfikowane przez czas okazały się trafniejsze niż poglądy wielu współczesnych mu polonistów.

Nawet tak wartościowe prace, niewznawiane drukiem od stu i więcej lat, często rozproszone po czasopismach przechowywanych przez największe biblioteki, są dziś właściwie niedostępne ogółowi wykształconych humanistów, znane może garstce wtajemniczonych badaczy akademickich. Reedycja ważniejszych studiów przynajmniej częściowo uchroniłaby od zapomnienia tych, którzy kiedyś tak wspaniale współtworzyli nasze narodowe dziedzictwo.

\section{BIBLIOGRAFIA}

\section{Źródła archiwalne}

Державний архів Львівської області м. Львів

Fond 26, opis 5, sprawa 370 (teczka osobowa Ryszarda Ganszyńca), sprawa 876 (teczka osobowa Jerzego Kowalskiego).

\section{Literatura}

Bersano-Begey M., Korespondencja A. B-a z W-tem Mickiewiczem, „Blok Notes Muzeum Literatury im. A. Mickiewicza" 1983, s. 53-57.

Borowy W., Edward Porębowicz jako krytyk i jako badacz literatury polskiej, „Przegląd Współczesny" R. 12, 1933, t. 44, nr 131, s. 331-354. 
Bruchnalski W., Lacińska i polska poezja w Polsce średniowiecznej [w:] Dzieje literatury pięknej w Polsce, praca zbiorowa, cz. 1, Kraków 1935, s. 47-121.

Ganszyniec R., Pieśń tacińska w szkole, czyli o rehumanizacji filologii klasycznej, Lwów 1937.

Ganszyniec R., Śpiew poezyj horacjańskich w szkole, Lwów 1935.

Kleiner J., Emil Petzold, „Słowo Polskie” R. 36, 1932, nr 198, s. 6.

Mikulski T., Miniatury krytyczne, przedmowa W. Weintraub, Warszawa 1976.

Prokop J., Edward Porębowicz [w:] Obraz literatury polskiej XIX i XX wieku, red. K. Wyka et al., seria 5: Literatura okresu Młodej Polski, t. IV, Kraków 1977, s. 253-274.

Słownik badaczy literatury polskiej, red. J. Starnawski, t. III, Łódź 2000, s. 158-160.

Smereka J., Filologia klasyczna w Uniwersytecie Lwowskim do czasów Zygmunta Węclewskiego i Ludwika Ćwiklińskiego, Lwów 1937 (odbitka z „Eos” 1937).

Smereka J., Pierwszy filolog-Polak w Uniwersytecie Jana Kazimierza Zygmunt Węclewski, Lwów 1938.

Starnawski J., Sylwetki lwowskich historyków literatury, Łódź 1997.

Terlecki T., Spotkania ze swoimi, Wrocław 1999.

Turasiewicz R., Ryszard Gansiniec [w:] Uniwersytet Jagielloński. Złota Księga Wydziału Filologicznego, red. J. Michalik, W. Walecki, Kraków 2000, s. 385-397.

Ulewicz T., Ryszard Gansiniec i jego badania nad kultura polskiego średniowiecza i renesansu, „Pamiętnik Literacki” R. 49, 1958, z. 4, s. 645-666.

Wasylewski S., Pożyczanie ksiażek do domu [w:] Zakład imienia Ossolińskich 1827-1956 $w$ dziesięciolecie działalności we Wrocławiu, red. nauk. W. Floryan, Wrocław 1956, s. $110-112$. 